\title{
Effect of torrefaction pre-treatment on physical and combustion characteristics of biomass composite briquette from rice husk and banana residue
}

\author{
Nor Amira Atan ${ }^{1, *}$, Munira Mohamed Nazari ${ }^{1}$, and Fathin Ayuni Azizan ${ }^{1}$ \\ ${ }^{1}$ School of Bioprocess Engineering, Universiti Malaysia Perlis, 02600 Arau, Perlis, Malaysia
}

\begin{abstract}
Biomass is an alternative renewable energy sources that can generates energy almost same as fossil fuel. The depletion sources of fossil fuel had increase the potential use of biomass energy. In Malaysia, rice husk and banana residues are abundantly left and not treated with proper disposal method which later may contribute to environment and health problems. Thus the development of biomass composite briquette made from rice husk and banana residue is one of the potential ways to reduce the problems and hence may contribute the better way to treat the waste by recycling the waste into a form of biomass product. The biomass briquettes are used for thermal applications because it can produce a complete combustion as it has a consistent quality and high burning efficiency. However, the quality of the biomass briquette can be added by application of torrefaction pre-treatment method. Torrefaction is a thermal method that can produce more high quality of the briquette with high calorific value, high fixed carbon content, low volatile matter, and low ash content. This study was conducted to assess the physical and combustion characteristic of the biomass briquette from rice husk and banana residue which was produced through torrefaction process. The biomass briquette, were densified by using hot press machine with temperature of $180^{\circ} \mathrm{C}$ for about 30 minutes. The briquette produce are $150 \mu \mathrm{m}$ in particle size with varies in mixing ratio of rice husk to banana residue which are 100:0, 80:20 and 60:40. After the briquetting process, the biomass fuel briquettes have been undergoes parameter testing and the data have been analysed. Result showed the best biomass briquette is developed from torrefied rice husk and banana residue mixed at ratio of 60:40. Moreover, SEM image reveal that torrefaction pre-treatment has shrinkage the fibres size which confirming the thermal stability of the briquette.
\end{abstract}

\section{Introduction}

Biomass briquette is a biofuel replacement to lignite-coal and charcoal which usually made from agricultural waste and other organic materials. Briquette is an alternative to fossil fuel as they are renewable, non-polluting and an economic of energy source. Biomass briquette produce through briquetting process where the waste material undergo densification to produce compact compounds with the use of pressure. Briquette is ideally sized for complete combustion as it has a consistent quality and high burning efficiency. However, the best quality of biomass briquette depends on some factors such as the crushing strength, moisture content, density, flame propagation and ash content value. A part from that, to get a good quality of biomass composite briquette it also needs low moisture content, ash content, and slow flame propagation in order to have uniform and complete combustion process.[1]

A research on combustion performance of biomass composite briquette from rice husk and banana residue had been done before and the result shows that the rice husk and banana residue with particle size of $150 \mu \mathrm{m}$ and mixing ratio of $60: 40$ have a huge potential to become a commercialized product by briquetting as it meets the properties for a good fuel briquette [2]. Table 1 shows the summary result obtained from the research.

Table 1: The physical and combustion performance of rice husk and banana residue briquette

\begin{tabular}{|l|c|}
\hline Parameter Testing & Value \\
\hline Density $\left(\mathrm{g} / \mathrm{cm}^{3)}\right.$ & 0.5675 \\
Ignition time $(\mathrm{s})$ & 26.32 \\
Burning rate $(\mathrm{cm} / \mathrm{s})$ & 0.2193 \\
Calorific value $(\mathrm{kJ} / \mathrm{kg})$ & 16305 \\
Ash content $(\%)$ & 12.91 \\
Volatile matter $(\%)$ & 75.43 \\
Fixed carbon content $(\%)$ & 11.66 \\
\hline
\end{tabular}

\footnotetext{
* Corresponding author: noramiraatan93@gmail.com
} 
In that research, the raw material was not treated with any pretreatment and the best combustion performance in term of calorific value is $16205 \mathrm{~kJ} / \mathrm{kg}$. However, the performance of the briquette can be better through addition of pre-treatment process. So that, the main purpose of this paper was to enhance the current production method of biomass composite briquette from rice husk and banana residue through torrefaction pretreatment method.

Torrefaction process is a thermal pretreatment for biomass taking place in temperature range of $200^{\circ} \mathrm{C}$ to $300^{\circ} \mathrm{C}$ at up to 30 minutes with the nonexistence of oxygen. According to J. S. Tumuluru et al. the torrefaction pretreatment enhance the biomass physical properties and increase from 15 percent to 25 percent of heating value of the briquette [3]. The torrefaction pretreatment towards the raw material improves the energy density and the overall fuel characteristic of the torrefied briquette. Figure 1 illustrates the flow diagram for basic production of torrefied biomass composite briquette.

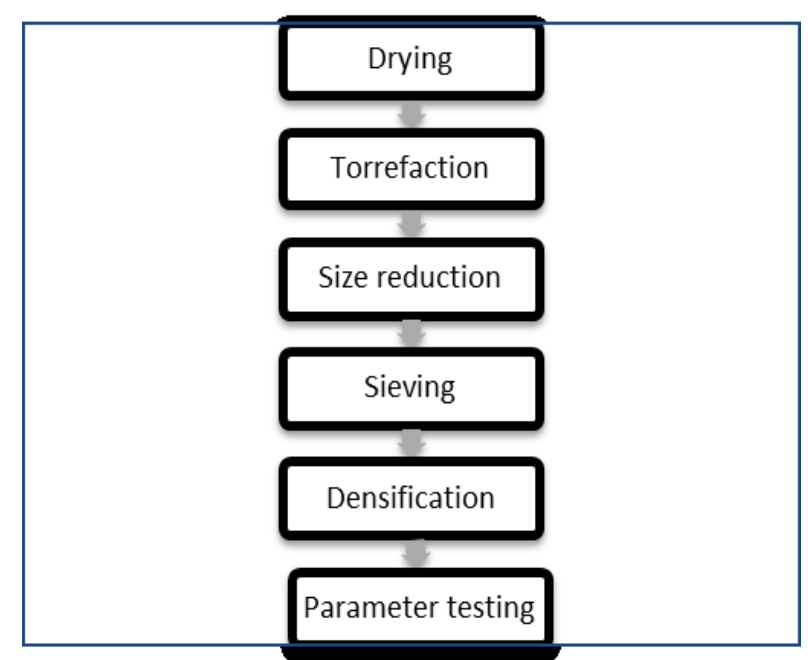

Fig. 1: Flow diagram for production of torrefied biomass composite briquette.

\section{Material and method}

The production of biomass composite briquette were starts from the collection and preparation of raw material, the pre-treatment process, size reduction, sieving and densification process. Then the biomass briquette produced were analysed of its physical, proximate and morphology.

\subsection{Collection and preparation of raw materials}

The raw materials which are rice husk and banana residue were collected from KBB Simpang Empat, Perlis rice mill and the nearby fried banana stalls. Then, sun dried method followed by oven dry method with temperature of $105{ }^{\circ} \mathrm{C}$ was applied in order to reduce the moisture content of the raw materials until it reached constant moisture content. The moisture content of the raw materials was then calculated as follow:

$$
\% \text { Moisture content }=\left(\mathrm{W}_{\mathrm{i}}-\mathrm{W}_{\mathrm{f}}\right) / \mathrm{W}_{\mathrm{i}} \times 100 \%
$$

Where $\mathrm{W}_{\mathrm{i}}$ and $\mathrm{W}_{\mathrm{f}}$ are weight of test raw materials before drying and when oven-dried, respectively in gram unit (g).

\subsection{Pre-treatment process}

The dried raw materials were then undergoing torrefaction treatment process. The rice husk and banana residue were placed in a furnace and torrefied at $300^{\circ} \mathrm{C}$ for 30 minutes. Figure 2 and Figure 3 shows the rice husk and banana residue after undergo the torrefaction pretreatment. Both of the raw materials were turns brown to black, which can be mainly because to the change in the chemical composition of the torrefied biomass.

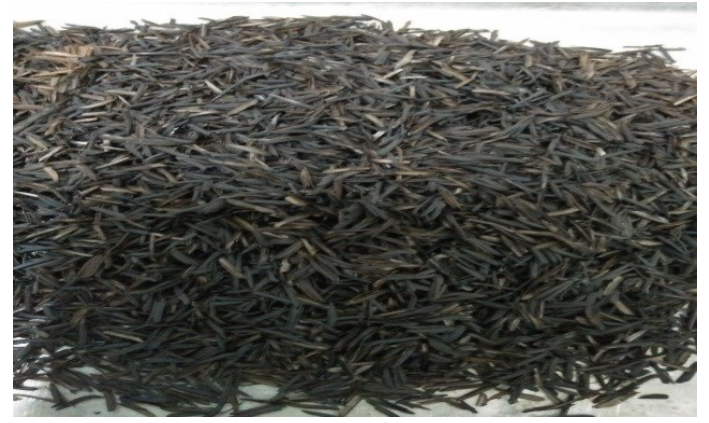

Fig. 2: Torrefied rice husk

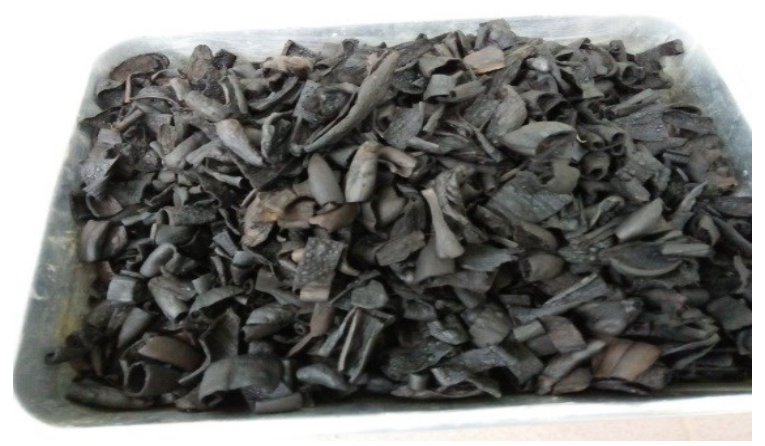

Fig. 3: Torrefied banana residue

\subsection{Production of biomass composite briquette.}

The torrefied samples were ground and sieved into small particle size $(150 \mu \mathrm{m})$ in order to increase the surface area of the material which improves on the binding and strength of the briquette samples before they were compacted. Then, the briquette was densified by using hot press machine as shown in figure 4 and mould size of $3.0 \mathrm{~cm} \times 3.0 \mathrm{~cm}$ with mixing ratio of rice husk and banana residue at 100:0, 80:20 and 60:40. Figure 5 shows the example of briquette produced after the densification process was done at temperature of $180^{\circ} \mathrm{C}$ for 30 minutes. 


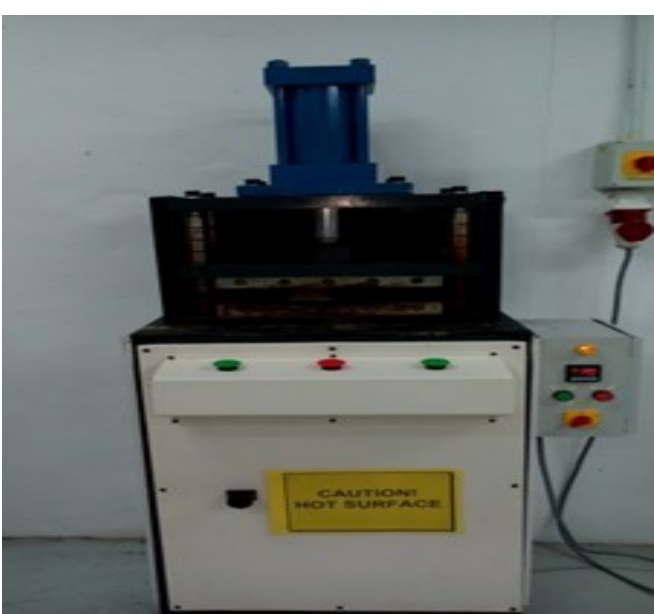

Fig. 4: Hot press machine

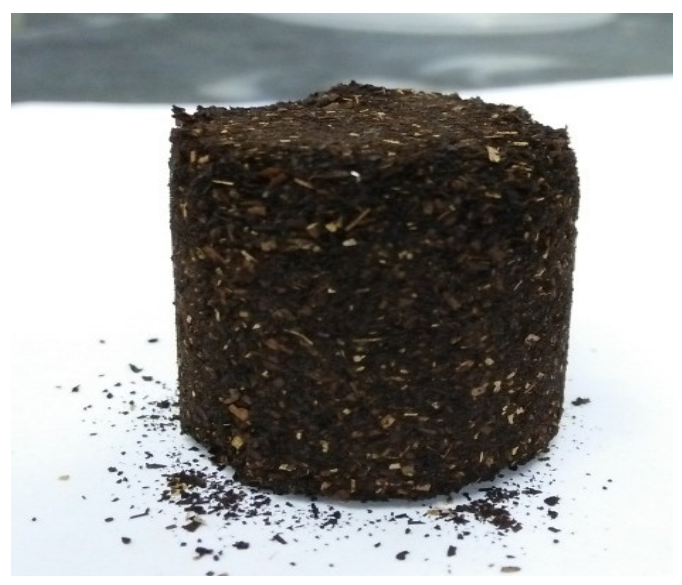

Fig. 5: Briquette produced made from mixing of torrefied rice husk and banana residue

\subsection{Physical and proximate analysis}

In this analysis, there were seven tests that have been done in order to complete the proximate analysis of the briquette and each analysis was replicated 3 times to ensure the accuracy of the results obtained. The analysis that were carried out were density, ignition time, combustion rate, ash content, volatile matter, fixed carbon content and calorific value. The methodologies summarized of proximate analysis were discussed below.

\subsubsection{Density}

Density was determined from the ratio of the mass over the volume of the briquette. Mass was taken by weighing the briquette on the digital weighing scale and volume using the formula of cylinder. Equation 2 shows the formula to calculate the density.

$$
\text { Density, } \rho=\text { mass/volume, }\left(\mathrm{kg} / \mathrm{m}^{3}\right)
$$

\subsubsection{Ignition time}

Each of the samples of the biomass composite briquette was ignited at a free corner. By using stop watch, the time taken for the flame to ignite was recorded as the ignition time.

\subsubsection{Combustion rate}

Combustion rate can be characterized as the portion of the mass of the fuel burn to the total time taken. The samples were placed on the wire gauze and the burner starts to ignite. Combustion rate was determined as follows:

$$
\text { Combustion rate }=\text { distance }(\mathrm{cm}) / \text { afterglow time }(\mathrm{s})
$$

\subsubsection{Ash content}

The ash content can be characterizes as approximate measure of the mineral substance and other inorganic matter in biomass. The biomass composite briquette was weighted before the burning process. At that point, the briquette was undergoing burning process by following the ASTM E1755-01 (2007) where the briquette were burned at $575{ }^{\circ} \mathrm{C}$ for 4 hours inside the furnace. Then, the weight of ash was determined by using analytical balance. Ash content was determined as follows:

$$
\% \text { Ash content }=\left(\text { Weight }_{\text {ash }}\right) /(\text { Weight } \text { sample }) \times 100
$$

\subsubsection{Volatile matter}

$2 \mathrm{~g}$ of the briquette sample were filled in the crucible and covered with a lid before it was placed in furnace at temperature of $550{ }^{\circ} \mathrm{C}$ for 10 minutes according to the ASTM 872-82 (2006). The crucible was cooled first in air inside desiccators and then the remaining samples were weighed again. Loss in weight was reported as volatile matter on percentage basis. The percentage of the volatile matter was calculated as follows:

$$
\% \text { Volatile Matter }=\left(\mathrm{W}_{\mathrm{i}}-\mathrm{W}_{\mathrm{f}}\right) / \mathrm{W}_{\mathrm{i}} \times 100 \%
$$

Where $\mathrm{w}_{\mathrm{i}}$ and $\mathrm{w}_{\mathrm{f}}$ is the weight initial and final of the samples briquette.

\subsubsection{Fixed carbon content}

The percentage fixed carbon was calculated using the equation of the sum of the percentages of ash content and volatile matter was subtracted from $100 \%$ in accordance with applying the mass balance for the biomass sample.

\subsubsection{Calorific value}

The calorific value of material was obtained by using Bomb Calorimeter (C 200 Basic), where the environment of the combustion was 25 atmospheric 
pressure of oxygen in a closed vessel which will be surrounded by water under controlled surrounding to ensure complete combustion according to test method of DIN 51900. After all briquettes samples were fully burned, the result of calorific value was show in $\mathrm{kJ} / \mathrm{kg}$.

\subsection{Morphology analysis}

The treated rice husk and banana residue were then analyzed and observed by using Scanning Electron Micrograph (SEM).

\subsubsection{Scanning Electron Micrograph (SEM) analysis}

SEM analysis was done in order to observe the surface morphology of the raw materials before and after the pretreatment process as effect from the torrefaction pretreatment to the rice husk and banana residue.

\section{Result and discussion}

\subsection{Physical and proximate analysis}

The result for this proximate analysis was discussed based on the effect of different mixing ration of torrefied rice husk and banana residue and the effect of torrefaction pre-treatment towards the briquette produced by comparing with the data stated in table 1 .

\subsubsection{Density}

Density is one of the important parameter to be tested in order to produce high quality of briquette. Density shows the compactness of briquette and the strength of the briquette is high as the density increases. Figure 6 shows the effect of mixing ratio of torrefied rice husk and banana residue on the density of tested briquettes.

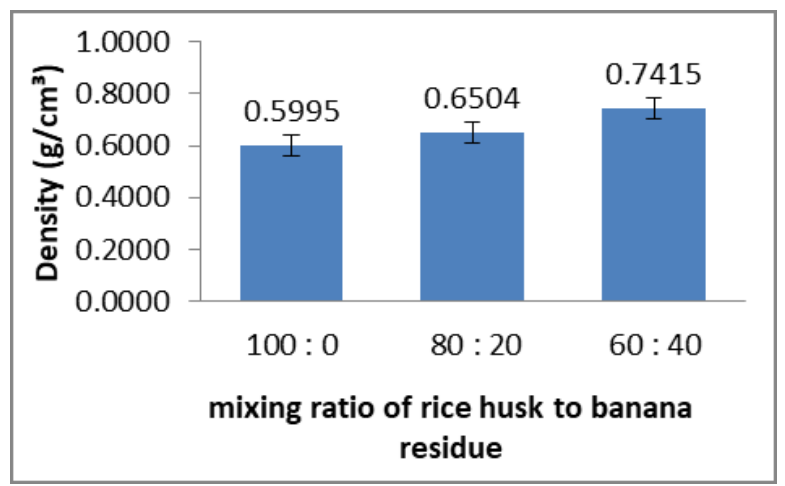

Fig. 6: Effect of different mixing ratio of torrefied rice husk and banana residue on density.

Based on the data obtain, the density for briquette made from mixing ratio of rice husk and banana residue at 100:0, 80:20, and 60:40 were $0.5995 \mathrm{~g} / \mathrm{cm}^{3}, 0.6504$ $\mathrm{g} / \mathrm{cm}^{3}$ and $0.7415 \mathrm{~g} / \mathrm{cm}^{3}$ respectively. The density of the briquettes was gradually increases with the increase ratio of torrefied banana residue. The addition of banana residue to the rice husk at $20 \%$ and $40 \%$ had influenced the density of the briquette produced as the density were increases up to $7 \%$ to $19 \%$ compared to the briquette comprised of $100 \%$ of torrefied rice husk. Moreover, the density of the briquette with torrefaction pretreatment also shows a good result with $30 \%$ density greater than briquette with untreated rice husk and banana residue. The torrefied raw materials can produce more compacted briquette than untreated because at the higher temperature of torrefaction process, depolymerization and devolatilization was occur where the lignin of the raw material were softens and make the raw materials more suitable for densification. Softened lignin of the raw materials helps in the compaction of the briquettes as one of the basic binding agent in densification process is the lignin content in the materials [3].

\subsubsection{Ignition time}

Ignition time is the time required for the briquette to start burning. The ignition time was tested in the control condition under fume hood with the movement of air velocity of $4.0 \mathrm{~m}^{3} / \mathrm{s}$. The data obtained for the effect of mixing ratio of torrefied rice husk and banana residue on ignition time is plotted in Figure 7.

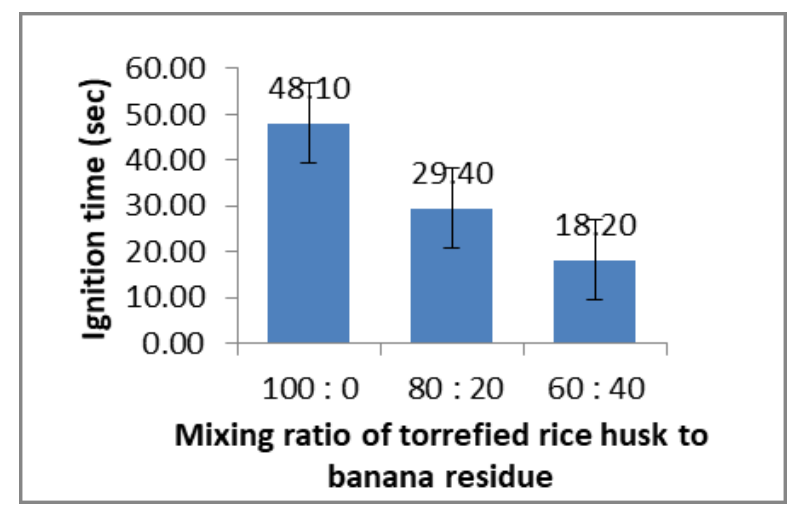

Fig. 7: Effect of different mixing ratio of torrefied rice husk and banana residue on ignition time

From the result it showed that the time required to ignite the flame is increase with decrease of mixing ratio of banana residue. At 100:0 mixing ratio the ignition time was 48.10 seconds whereas there was taken 29.40 seconds for mixing ratio 80:20. Meanwhile, the shortest ignition time of 18.20 seconds was recorded in briquette produced from mixing ratio of $60: 40$. The upswing in the ignition time with increase mixing ratio of rice husk indicates that rice husk has flame retarding and selfextinguishing as when the mixing ratio was 100 percent of rice husk it took the longest time and difficult to ignite. However, when comparing with the untreated biomass briquette, the torrefaction pretreatment process had contributed to the low ignition time. The ignition time obtain for torrefied biomass briquette was reduced approximately $30 \%$ from the untreated biomass briquette made from rice husk and banana residue. The higher ignition time produced from the untreated biomass 
briquette is due to the silica content inside the rice husk after the burning process. The torrefaction pretreatment process had reduced the silica formation during the combustion at once had reduced the time taken for the briquette to ignite.

\subsubsection{Combustion rate}

Combustion rate is the burning rate during the burning process of the briquettes. It is measured by measuring the distance of burning briquette over time taken to burn the briquette. Figure 8 illustrated the effect of different mixing ratio of torrefied rice husk and banana residue on combustion rate.

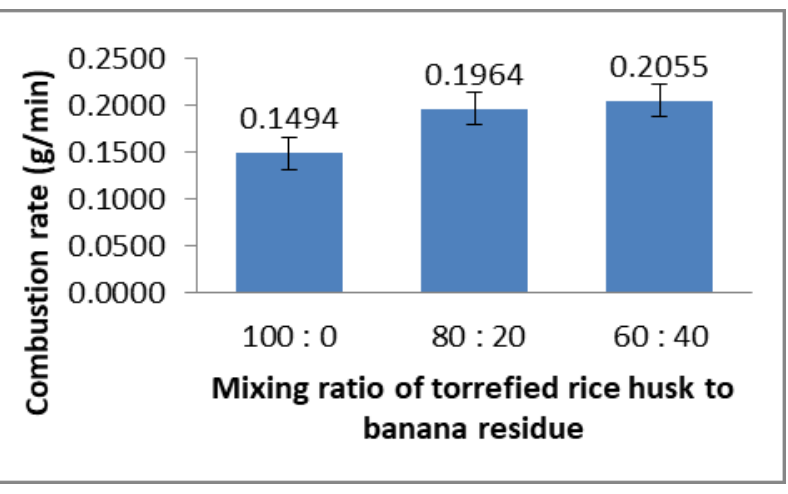

Fig. 8: Effect of different mixing ratio of torrefied rice husk and banana residue on combustion rate

Based on the result, the combustion rate increased with the increased ratio of banana residue. It was recorded that when the mixing ratio is 100:0, 80:20 and $60: 20$ the combustion rate was $0.1494 \mathrm{~g} / \mathrm{min}, 0.1964$ $\mathrm{g} / \mathrm{min}$ and $0.2055 \mathrm{~g} / \mathrm{min}$ respectively. Rice husk can be burnt at longer duration for the combustion process due to its flame-retarding condition. The reason for this situation was same as the reason which stated at ignition time. It was not easily to ignite the briquette with 100 percent of rice husk as these situations occur because of at certain temperature reached, the molecular bond between the silica and carbon inside the rice husk was strengthened and this compound formed a hamper to prevent oxygen reaching to the carbon inside [4]. Thus, it was not easily to burn with open flame. The difficulty of burning cause the burning rate slower and mean that required longer time for combustion.

\subsubsection{Ash content}

Ash is the non-burnable component of biomass and it impact on the heat transfer to the surface of the briquette as well as the diffusion of oxygen to the briquette surface during the briquette's combustion. The bar chart in Figure 9 shows the effect of different mixing ratio of torrefied rice husk and banana residue on ash content.

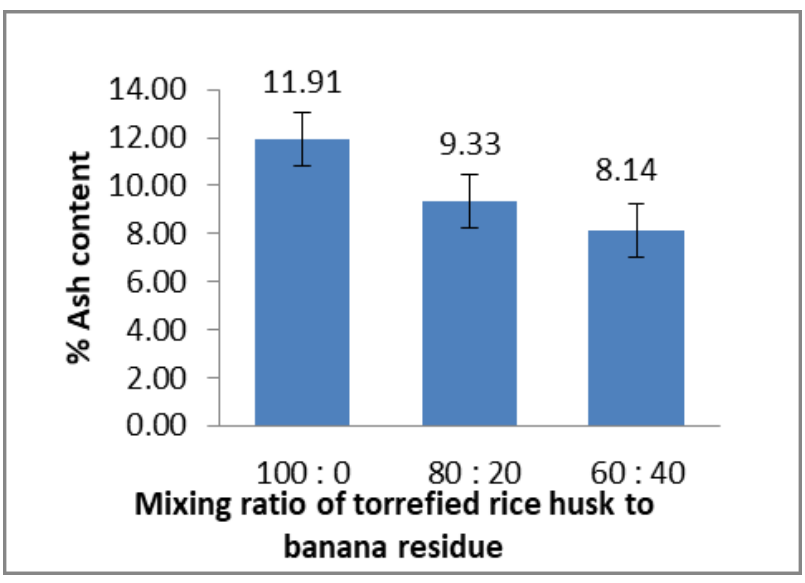

Fig. 9: Effect of different mixing ratio of torrefied rice husk and banana residue on ash content.

The biomass composite briquette with $100 \%$ of rice husk burned with highest percentage of ash content followed by composite briquette with mixing ratio of 80:20 and 60:20 of torrefied rusk husk and banana residue. This result indicates that, the higher amount of banana residue, the lower the percentage of ash content. Thus, it proves that, banana residue helps in reducing the non-combustibles component in the briquette. In addition, when comparing with the untreated briquette of rice husk and banana residue, the torrefaction pretreatment were able to reduce the percentage of ash content from $8 \%$ to $36 \%$. The low ash recorded is a reflection of the high heating value obtained in the briquette made with the torrefied raw materials. High ash content produced by the briquette regularly cause to the lower heating value during combustion process .High ash content results into dust emissions which lead to air pollution and affects the combustion volume and efficiency. The higher the fuel's ash content, thereby lowering the briquette's calorific value since it bring the impacts to the burning rate due to minimization of the heat transfer to fuel's interior parts and diffusion of oxygen to the briquette surface during briquette combustion [5]. Hence, briquettes made from torrefaction pre-treatment of raw materials are most suitable for cooking compare to the briquette without treatment as it has lower ash content.

\subsubsection{Volatile matter}

Volatile matter is the percentage component of oxygen, carbon and hydrogen that turn into vapor when heated [6]. The effect of different mixing ratio of torrefied rice husk and banana residue on volatile matter is shown by bar chart in Figure 10. 


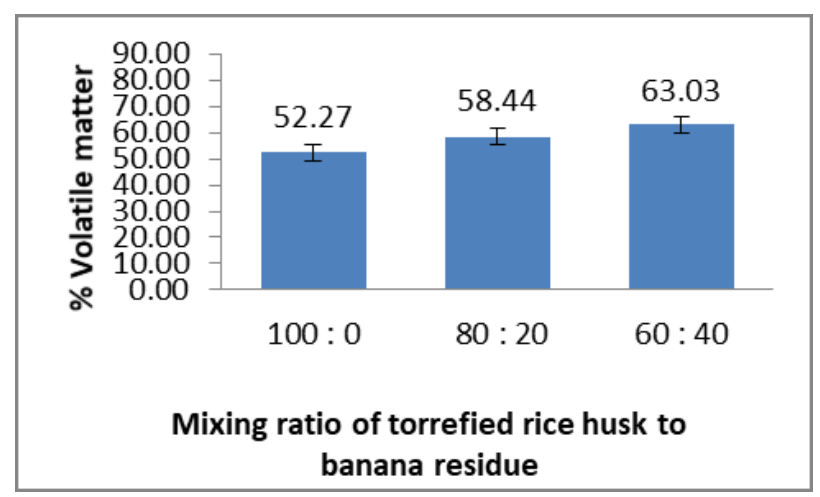

Fig. 10: Effect of different mixing ratio of torrefied rice husk and banana residue on volatile matter.

From the results, the higher percentages of volatile matter release obtain by briquette made from mixing ratio of $60: 40$ which is $63.03 \%$ compare to the briquette made from mixing ratio of $80: 20$ and 100:0 with $58.44 \%$ and $52.27 \%$ volatile matter respectively. The additional amount of banana residue had increase the percentage of volatile matter of the briquette. Besides, by comparing to the untreated and torrefied composite briquette of rice husk and banana residue, the torrefied briquette had a better result where the briquette with torrefaction pretreatment had decrease the percentage of volatile matter at $16 \%$ compare to the untreated briquette. This result because of during the torrefaction process, the hydrogen and oxygen component in the raw materials were decrease due to the water $\left(\mathrm{H}_{2} \mathrm{O}\right)$ formation during the thermal process.

\subsubsection{Fixed carbon content}

Fixed carbon content represents the percentage of carbon available for char combustion after the percentage of volatile matter and ash content is refined off. The fixed carbon content also gives an indication for the percentage of char that remains after the devolatilization phase. Graph in Figure 11 shows the effect of different mixing ratio of torrefied rice husk and banana residue on the briquette's fixed carbon content.

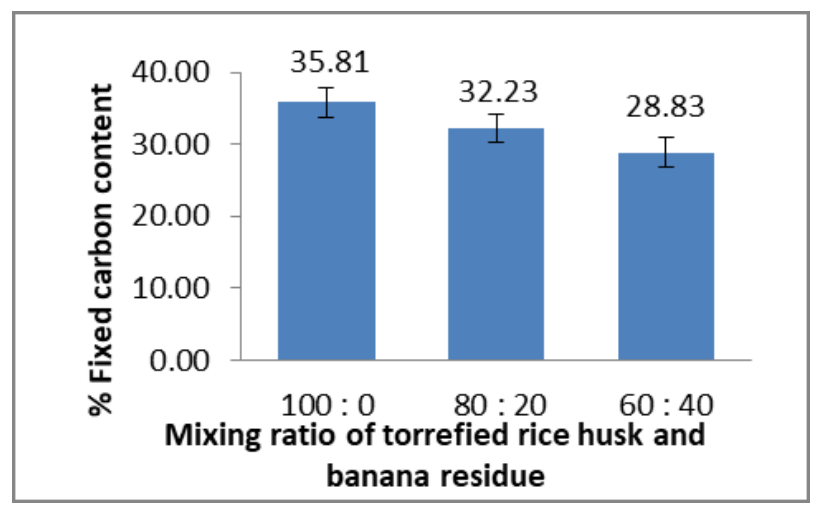

Fig. 11: Effect of different mixing ratio of torrefied rice husk and banana residue on fixed carbon content.
According to the graph above, the briquette comprise of 100 percent of rice husk have the highest percentage of fixed carbon compare to the briquette mixed with mixing ratio of $80: 20$ and 60:40. This result was obtained because of the influence by the result from percentage of ash content and volatile matter. The percentage of fixed carbon is inversely proportional to the percentage of ash content and volatile matter. The lower the percentage of ash content and volatile matter of the briquette produce, the higher the percentage of fixed carbon. A better briquette is produce when the percentage of fixed carbon content is increase as particularly the corresponding gross calorific value produce from the briquette will increase too. As the result, the higher the fixed carbon content, the higher heat release and making it tends to reduce the cooking time.

\subsubsection{Calorific value}

The calorific value or heating value is the amount of heat released during the combustion of a specified amount of it. Figure 12 shows the relationship of different mixing ratio of torrefied rice husk and banana residue on the gross calorific value of the tested briquette.

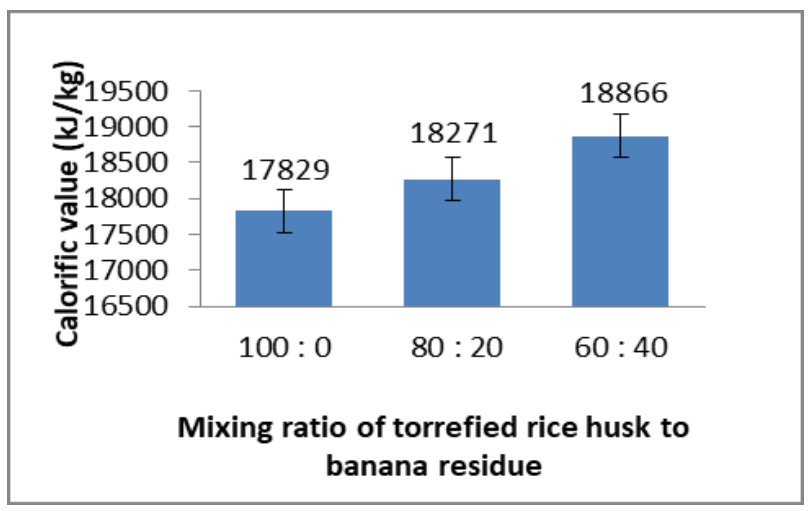

Fig. 12: Effect of different mixing ratio of torrefied rice husk and banana residue on calorific value

Based on the graph in Figure 12 the gross calorific value were increases with the increase ratio of banana residue in the mixture of the briquette. The value recorded were $17829 \mathrm{KJ} / \mathrm{Kg}, 18271 \mathrm{KJ} / \mathrm{Kg}$ followed by $18866 \mathrm{KJ} / \mathrm{Kg}$ for the briquette made from $100 \%$ of rice husk, $80: 20$ and $60: 40$ mixing ratio of rice husk and banana residue respectively. The higher calorific value obtained from the briquette indicated that the briquette produced is better to be burned. In addition, it can be said that the torrefied rice husk and banana residue briquettes were successfully produced. According to the result obtain, by torrefaction pretreatment it had increase $16 \%$ of calorific value compared to the untreated rice husk and banana residue briquette that were tested before. The rice husk and banana residue were loses generally more moisture content, oxygen and hydrogen than carbon during torrefaction, which increases the result in calorific value of the briquette 


\subsection{Morphology analysis}

\subsubsection{SEM}

The micro and macro structure of the samples were observed with the purpose of gaining a more profound into the impact of torrefaction on the structural change of the torrefied material and compare this change with the untreated raw material. The SEM images of the torrefied and the raw samples of rice husk and banana residue were taken under the same analysis condition (magnification was $\times 500, \times 1000, \times 3000$ and $\times 5000$ at $10 \mathrm{kV}$ for the comparison results. The images are presented in Figure 13.

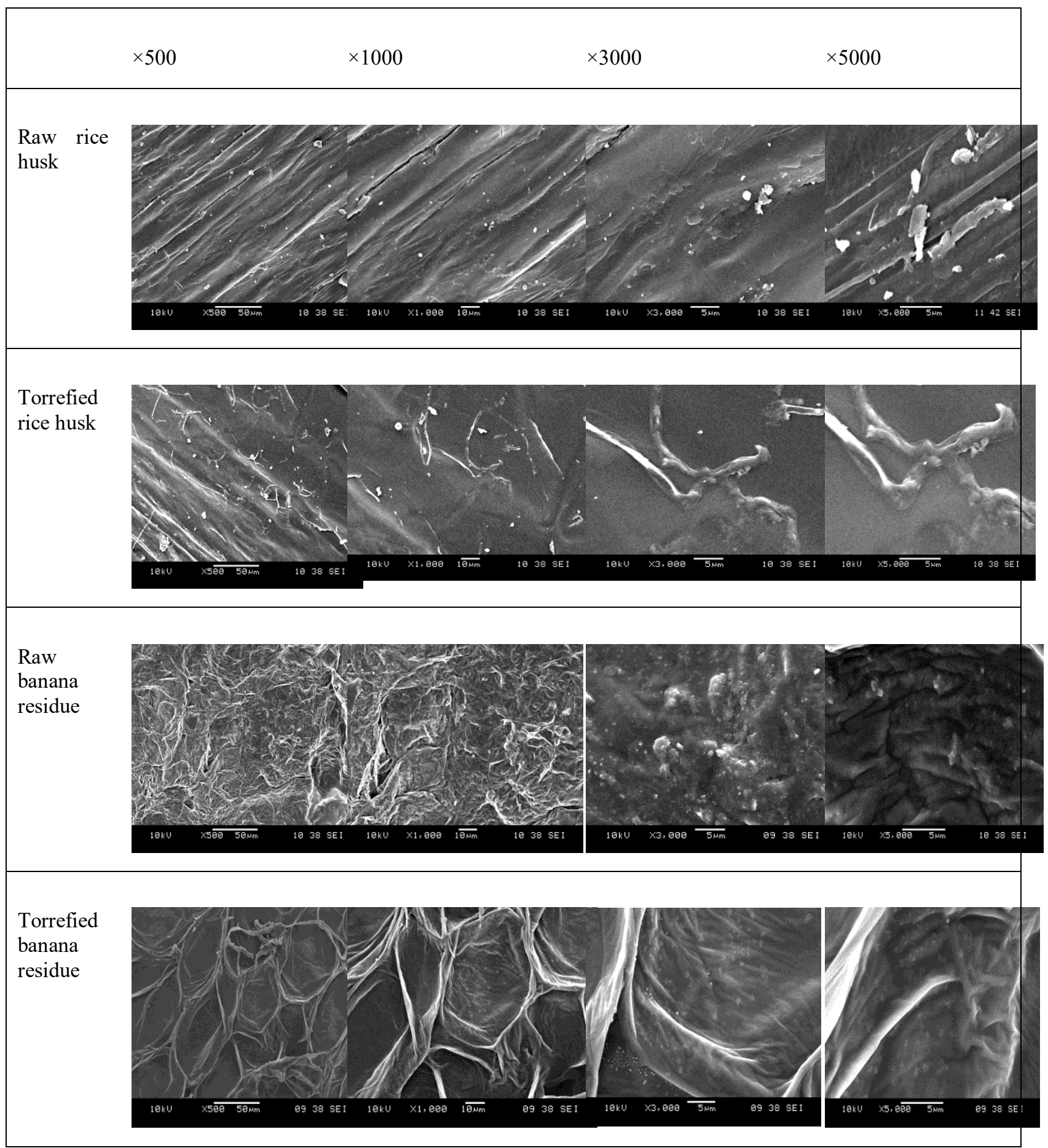

Fig. 13: SEM images of raw rice husk, torrefied rice, raw banana residue and torrefied banana residue with $\times 500$, $\times 1000, \times 3000$ and $\times 5000$ magnification. 
Based on Figure 13 it is evidence that the untreated and torrefied rice husk and banana residue exhibit different surface morphology under the analytical scanning electron microscope (JOEL JSM 6460 LA). Based on the observation, both untreated raw rice husk and raw banana residue appears lighter in colour with rough surface compare to the rice husk and banana residue that have been undergo the torrefaction pretreatment. It cannot be explained well the effect of pretreatment to the morphology of the rice husk as there are not much different that are noticeable on the surface structure of the both untreated and torrefied samples. However, for both samples of untreated and torrefied banana residue it is clearly observed that the torrefaction pretreatment had changed the raw materials surface as the structure of torrefied banana residue shows a porous structure like honey comb. This situation obviously can be attributed to the thermal pretreatment that may have decomposed the hemicellulose and some weak part of lignin component in the raw material.

\section{Conclusions}

Based on the physical and combustion performance, the biomass briquette from rice husk and banana residue which undergo torrefaction pre-treatment process exhibit more excellent potential as an alternative energy source compare to biomass briquette without torrefaction process. Torrefaction pre-treatment methods enhance the quality of briquette produce as torrefaction has shrinkage the fibers size which confirming the thermal stability of the briquette. In this project the torrefaction was done at $300^{\circ} \mathrm{C}$ for 30 minutes. From morphology analysis, it showed torrefaction will shrinkage fiber size on biomass sample which confirming the thermal stability of biomass briquette produce later. This project showed that the torrefaction pre-treatment and the mixing ratio of the raw materials used will affect the parameters such as density, ignition time, combustion rate, ash content and the calorific value. The study of this project shows that there are relatively relationships between the pretreatment and mixing ratio with the parameter tested. From all of the parameter testing, it was found that the best briquette was the briquette made from mixing ratio of torrefied rice husk and banana residue at 60:40 as it meets the properties for a good fuel briquette. The energy values and combustion qualities of the briquettes produced in this study are also sufficient enough to produce the required heat for domestic cooking and also for industrial application especially the energy requirement of the small-scale industries.

The authors would like to acknowledge the support from the Research Acculturation Grant Scheme (RAGS) under a grant number of RAGS/1/2015/UNIMAP/9018-00087 from the Ministry of Higher Education Malaysia.

\section{References}

1. Oladeji, J. (2012). Comparative Study of Briquetting of Few Selected Agro-Residues Commonly Found in Nigeria. Pacific Journal of Science and Technology, 13(2), 80-86.

2. M. M. Nazari, C. P. San, N. A. Atan. (2016) Performance of Biomass Composite Briquette from Rice Husk and Banana Residue. The National Seminar of Indonesian Society of Agricultural Engineers (PERTETA).

3. J. S. Tumuluru, S. Sokhansanj, J. R. Hess, C. T. Wright, and R. D. Boardman. (2011) A Review on Classification and Composition, Co-firing Issues and Pretreatment Methods. American Society of Agricultural and Biological Engineers (ASABE).

4. Olivier, P. A. (2002). The Rice Hull House, 1-13.

5. Nasrin, A.B., Ma, A. N., Mohamad, S., Choo, Y. M., Rohaya, \& Azali, A. (2006). Production of palm-based biomass briquettes Retrieved on Nov 25, 2016 from MPOB. At: http://palmoilis.mpob.gov.my/publications.

6. T. Nottingham and N. E. User. (2010) "Combustion Characteristics of Biomass Briquettes by Joel Chaney, MSci Physics with French,"

\footnotetext{
${ }^{*}$ Corresponding author: noramiraatan93@gmail.com
} 